\title{
Brief considerations on the conflict between public environmental protection and economic development policies and their consequences for energy expansion in Brazil
}

\begin{abstract}
The present paper aims to make brief considerations on the planning of the energy infrastructure, Brazilian economic development and the environment. This analysis will be conducted based on the conflicting public policies for economic development and environmental protection. This conflict brings difficult to plan the expansion of the Brazilian energy sector efficiently, reduces the competitive capacity of the country and does not provide adequate environmental protection. The most serious problem concerning the clash between economic development and environmental protection is deciding, while striving for maximum efficiency, which would cause more harm to society and should be avoided. In the Brazilian legal system between economic development and environmental protection, the Brazilian state will always come down on the side of the environment. Considering the proposed goals, the study will involve the consultation of documents and the literature in addition to exploratory research.
\end{abstract}

Ana Paula Myszczuk anap@utfpr.edu.br Universidade Tecnológica Federal do Paraná, Curitiba, Paraná, Brasil

KEYWORDS: Sustainability. Economic development. Public Policies. 


\section{INITIAL CONSIDERATIONS}

Throughout the nineteenth and twentieth century's, the world underwent what has come to be known as an industrial and biotechnological "revolution". From the birth of factories, to the development of new technologies and how energy is used, the sciences have introduced a new dynamic into daily life. At the same time, the world is experiencing a period of unparalleled environmental degradation.

In this context, Law and Economics have entered the twenty-first century, and lawmakers and economists are facing the challenge of engaging in and harmonizing conflicts or perplexities that have resulted from the struggle between the right to economic development and the right to an ecologically balanced environment. This means that on the one hand there is the prerogative that human beings have the right to enjoy nature in its original or in an artificial form in a way that fully enables the existence, protection and development of present and future generations of humanity and other living organisms. On the other hand, the fundamental right to economic development should be observed, through the use of natural and artificial resources for the improvement of human living conditions for the generations of today. In other words, a major challenge today is the creation of instruments that enable both economic development and protection of the environment. Ecological and economic sustainability means seeking a balance between social development, economic growth and the use of natural resources with a view to adequate territorial planning. Currently, the expansion of the energy structure in Brazil is planned separately from and in conflict with environmental requirements. We are not succeeding in overcoming the challenges of the twenty-first century. This conflict often results in compromised economic development, increased production costs and a reduction in the competitive capacity of the country.

With these issues in mind, the present study aims to reflect on the planning of the energy infrastructure, Brazilian economic development and the environment. This analysis will be conducted based on the conflicting public policies for economic development and environmental protection, which make it difficult to plan the expansion of the Brazilian energy sector efficiently. The conflict also reduces the competitive capacity of the country and does not provide adequate environmental protection. Considering the proposed goals, the study will involve the consultation of documents and the literature in addition to exploratory research.

\section{REGULATORY FRAMEWORK: THE ENVIRONMENT AND ITS LEGAL PROTECTION}

On a worldwide scale, since the mid twentieth century, concern over environmental preservation, curbing degradation and preventing damage to the environment has been an important issue. One of the results of these concerns was the Declaration of the United Nations Conference on the Human Environment, or Stockholm Declaration, which states that: 
established and fundamental goals of peace and of worldwide economic and social development." (Declaration of the United Nations Conference on the Human Environment, Item 6).

The principle of sustainable development, a concept consolidated by the World Commission on Environment and Development in 1987 was conceived as "development that satisfies the needs of present generations without jeopardizing the ability of future generations to meet their needs" (OUR COMMON FUTURE). The purpose here is to avoid attacks against the environment, establishing that it is necessary to think ahead and prioritize to actions that avoid, reduce, correct or remove any chance of the environment being harmed.

According to the Earth Summit $2002(\mathrm{RIO}+10)$, the term sustainable development is defined as "development that satisfies the needs of present generations without jeopardizing the ability of future generations to meet their needs". This definition from Our Common Future (1987) is even more accepted, but due to its scope it can be used to justify almost any activity providing that this activity reserves resources and means for future generations. In a stricter sense, it means that all current activities should be carefully evaluated to gauge their environmental impact.

This initial concern of the United Nations was given greater exposure at the Convention on Biological Diversity, which was held in Rio de Janeiro in 1992. Here it was determined that the "States have, in accordance with the Charter of the United Nations and the principles of international law, the sovereign right to exploit their own resources pursuant to their own environmental policies, and the responsibility to ensure that activities within their jurisdiction or control do not cause damage to the environment of other States or of areas beyond the limits of national jurisdiction." More recently, the Cartagena Protocol (2003) reaffirmed the precautionary approach of Principle 15 of Earth Summit 2002, which emphasizes the duty to exercise caution or abstain from practices that might cause damage to the environment.

The precautionary principle may be considered one of the greatest innovations in Environmental Law in the twentieth century. Owing to its innovative nature, this principle places collective responsibility on the State to avoid serious or irreversible damage to the environment, even if there is as yet a lack of scientific certainty that such damage is being caused. In other words, costeffective and preventive measures should be taken to attack the causes of environmental degradation. The damage does not need to have been done for steps to be taken to protect the environment. The mere threat or possibility demands that precautionary measures should be taken. This international legislation, its principles and precautions were introduced in Brazil, principally in the terms of the Brazilian Federal Constitution of 1988.

In the 1988 Constitution of the Federative Republic of Brazil, it is stated in Article 3, II that the guarantee of national development is one of the objectives of the Brazilian state. It is clearly understood that the term development includes sustainability, combining economic development and environmental protection. To meet this goal, Chapter VI of the Federal Constitution of 1988 focuses on the 
environment and enforces the principle of sustainable development (Article 225). To achieve these aims and attend to environmental protection, the country enacted a series of public policies specifically for energy and the environment.

Public policies can be viewed as "government action programs to coordinate the means available to the State and private enterprise for the achievement of socially relevant and politically determined goals" (BUCCl, 2002). A public policy also ought to consist of "an action meant to affect certain people and which involves the use of public resources" (BONETI, 2006). In other words, it can be understood as "the result of the dynamic of power games that establish relationships that are constituted by economic and political groups, social classes and other organizations of civilian society" (BONETI, 2006).

Thus, the aim of a public policy is to establish a means to an end, i.e., what the policy is meant to achieve and how results are achieved. In other words, "the formulation of a public policy consists of a process; and government actions are the decisions resulting from this process" (BUCCl, 2002). Therefore, public policies are made up of a group of programs that will be enacted by the State for as long as it has sufficient political clout to demand that the program be executed.

Although public policies have this integrated concept, it will be shown as this text progresses that policies for environmental protection and policies for economic development, especially in the energy sector, are at odds, as they are airtight and do not converge or overlap. This means that the limits on economic development that are enforced by environment protection principles become ineffective because they do not protect the environmental assets of the country and do not allow the country to become more competitive. This leads to an increase in what is known as the "Brazil Cost" ("Custo Brasil") - "Brazil Cost" is a general term used to describe the structural, bureaucratic and economic difficulties that increase the cost of investing in Brazil, hindering national development, causing rises in unemployment, informal labor and tax evasion. For this reason, it is known as a set of factors that compromise the competitiveness and efficiency of Brazilian industry.

The Brazilian National Environmental Policy aims to preserve, improve and regain environmental quality to improve living conditions and ensure conditions for socio-economic development and national security and protect the dignity of human life.

In this policy, the environment is considered a public asset to be guaranteed and protected and used collectively. To this end, it adopts the principles of rationalization for the following purposes: the use of the soil, subsoil, water and air; planning and inspection of the use of environmental resources; protection of ecosystems and monitoring and zoning of activities that cause pollution or have the potential to do so; incentives to study and research technologies for the rational use and protection of environmental resources; monitoring environmental quality levels; recuperation of degrades areas and the protection of areas threatened with degradation. 
For these principles to be effective, tools are required, such as an environmental impact assessment, licensing and a review of activities that cause, or have the potential to cause, pollution. Environmental licensing is an administrative procedure through which the competent environmental agency issues permits for the implementation, growth and operation of ventures that could potentially cause environmental degradation. These permits set the conditions for entrepreneurs to implement, operate and expand their ventures.

An environmental permit is not permanent and failure to comply with its conditions can lead to it being suspended or even revoked. According to Araújo (2002), when there is a significant potential for environmental degradation, an environmental impact study (EIS) is conducted prior to the issue of the environmental permit. A draft EIS is written in language that is easy to understand and the environmental impact report (EIR) is then issued.

Furthermore, it is necessary to comply with the terms of CONAMA Resolution 06/87, which regulates environmental licensing for ventures involving the exploration, generation and distribution of electricity. For hydroelectric ventures, a preliminary permit must be applied for during the study that determines the feasibility of the power station. Meanwhile, the installation permit should be obtained prior to the bidding on the construction of the plant. The operation permit has to be obtained before the closing of the dam.

In the case of thermoelectric power plants, the preliminary permit must be obtained in the early stages of the feasibility study, the installation permit before the venture is initiated and the operation permit following tests and before the plant begins to produce energy for commercial purposes. In the case of permits for substations and transmission lines, the preliminary permit should be applied for in the early planning stages of the venture, before its location has been decided. The installation permit should be sought following the conclusion of the executive project and before construction work has begun. The operation permit should be applied for prior to the commercial operation of the station.

\section{RESULTS AND DISCUSSIONS: THE BRAZILIAN MODEL FOR THE USE OF ENERGY}

\section{THE CASE OF HYDROELECTRICITY}

It was in the 1950s that the engineer Catullo Branco presented the first project for a hydroelectric enterprise in Brazil, combining the generation of electricity with navigation. Through public policies involving the participation of the capital of private electric companies at the time, the first national energyproducing facilities became a reality. These facilities in São Paulo State were responsible for $20 \%$ of the electricity produced in Brazil until the 1980s (BRANCO, 2002).

It should be highlighted that the history of the planning for energy in Brazil was affected by the political and economic changes of the 1970s and 1980s, and the transition to hydroelectric power was inevitable. In the mid 1990s, approximately $15 \%$ of Brazil's foreign debt was due to investment in the 
construction of hydroelectric power plants, which had a better cost-benefit ratio at the time (REIS; FADIGAS; CARVALHO, 2012).

The transnational model that was established from 1940 to 1960 put public companies in the hands of federal and state governments, and these were responsible for a considerable part of the production and distribution of electricity, petroleum and gas. Petrobras, Eletrobrás and numerous companies from the states were created for this purpose, with their tasks including the planning for energy.

This model worked well until the mid-1980s, with costs being kept low and resulting in economic development. But it also created some problems. These included:

1. Artificially low electricity prices, which was a common practice for almost all public utilities and services run by the federal government in an effort to curb inflation.

2. The political use of companies that produced gas and electricity, with incompetent management and the building of numerous hydroelectric plants in order to obtain political benefits without the resources necessary to complete them. This would ensure a minimum economic return.(GOLDEMBERG; LUCON, 2007)

Today, the Brazilian energy matrix is recognized internationally for its potential for renewable sources, especially the hydroelectric companies (REIS; FADIGAS; CARVALHO, 2012). According to the National Energy Balance (2014), in 2013 the share of renewable sources in the national energy matrix remained at $41 \%$, one of the highest on the globe, whereas for the rest of the world, it was no higher than $13.2 \%$ and $8 \%$ in the countries of the OCDE (Organization for Economic Co-operation and Development).

Despite this impressive potential for renewable energy, the country uses only $5 \%$ of its total installed capacity in the generation of electricity from this source. According to the European Renewable Energy Council (EREC) (2010, p. 6), "in Brazil, the total energy that could be used with current technologies is 26.4 times higher than national demand". This information reveals the underachievement of this potential and the lack of an integrated energy policy.

Among the realistic alternatives of the national context, hydroelectricity remains the option that offers Brazil the best potential for the use of existing resources, including the Small Hydroelectric Plants (SHPs) - small hydropower plants are hydroelectric stations ranging between 1 and 30 megawatts. Their total flooded area is no higher than $13 \mathrm{~km}^{2}$ and they cause fewer social and environmental impacts than large hydropower plants (GONDEMBERG, 2010). On the other hand, there is controversy at the national and international level regarding the real environmental impacts of small hydros, which together may cause the same damage as one large hydro. According to Leite (2011), this debate has been mostly emotional and ideological and does not consider that there are both benefits and burdens that result from the use of this source, just as there are during any human intervention in nature. 
Due to the unfavorable hydrologic conditions observed in 2012 and 2013, there was a drop in the supply of hydropower, while the supply of other sources expanded, as shown in Figure 1. It is important to mention the importance of wind power in the national energy matrix and the efforts to expand the use of this source, which grew by 32.6\% in 2012 (NATIONAL ENERGY BALANCE, 2014).

Figure 1 - Internal energy supply

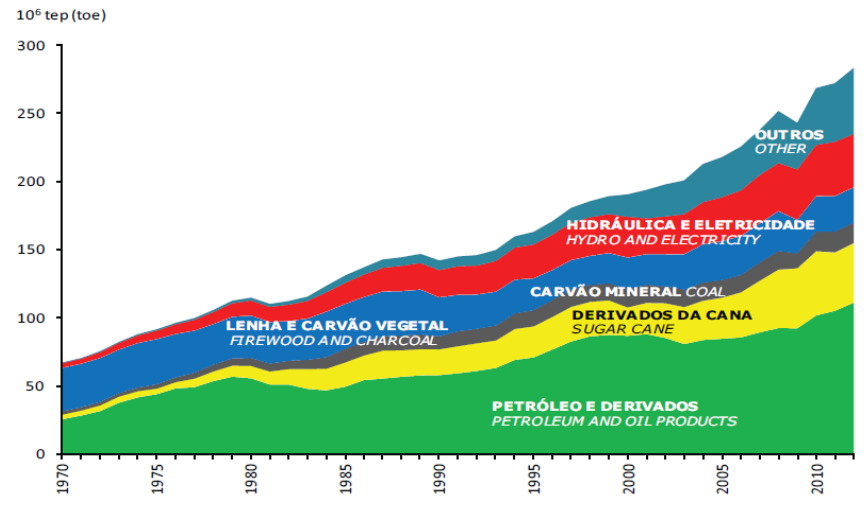

Source: National Energy Balance (2014, p.22)

According to Leite (2011), in the Brazilian energy context, the predominance of hydroelectric power due to its cost and renewability was called into question once again during the energy crisis of 2001 and because of the recent use of thermoelectric plants - In 2013, the share of thermoelectric energy was 31\%, rising from 24\% in 2012 (ENERGY PLANNING COMPANY, 2014).

In 2013, final energy consumption was supplemented by the expansion of thermal energy, especially plants that operate on mineral coal $(+75.7 \%)$, natural gas $(+47.6 \%)$ and sugarcane bagasse $(+19.2 \%)$. Their share in the electric matrix, in comparison with 2012 , rose from $1.6 \%$ to $2.6 \%$, from $7.9 \%$ to $11.3 \%$, and from $4.2 \%$ to $4.9 \%$, respectively (EPE, 2014). The lower supply of hydroelectric energy may account for the shrinking share of renewables in the Brazilian electricity matrix, despite an increase of 1,724 MW of installed power at the hydroelectric plant (NATIONAL ENERGY BALANCE, 2014).

Furthermore, there were thermal losses of $48 \%$ due to public thermoelectric generation to complement the low performance of hydraulic generation. Even so "the Brazilian economy, on average, remains 1.25 times less intense in carbon than the European economy, twice less than the American economy and four times less than the Chinese economy" (NATIONAL ENERGY BALANCE, 2014).

Renewable energy has good long-term prospects, although more resources are required for the development of more accessible technologies and the formation of a secure regulatory framework for investors. Brazil has agencies that are responsible for planning and expanding the energy axis. However, adapting to new economic, social and environmental parameters has to be rethought in a country that, in 2014, is not using its full production capacity. 
Brazilian energy policy is currently centered on hydraulic energy, which will remain the strategic priority for increasing supply. Evidence of this is the current building of large plants, especially those of "Santo Antônio (3,150 MW) and Jirau $(3,300 \mathrm{MW})$, both on the River Madeira, and Belo Monte (11,233 MW) on the River Xingu, all in the Amazon Basin" (EPE, 2012).

The sector of the Brazilian population that does not have access to electricity is made up of people on low incomes, and the high prices and quality that surpasses expectations exclude these people, leading them to access the electricity supply illegally. If the national goal is to improve levels of growth and development in the country, it is clear that expanding the supply of electricity is a democratic process and it can be concluded that it is necessary to discuss the balance between competitiveness and sustainability.

\section{THE NATIONAL ENERGY PLAN}

When it comes to expanding the infrastructure, the legal responsibility for planning the national energy matrix is in the hands of the Ministry of Mining and Energy. The National Energy Matrix 2030 and the National Energy Plan are the main support instruments for simulating different market scenarios, guiding policy makers. The decisions they have to make include evaluating restrictions, structural bottlenecks, systemic vulnerability, risks and business opportunities, directing public policies and the impact of the strict Brazilian environmental legislation on large projects.

The planned horizon of the National Energy Matrix 2030 includes the expansion of the energy supply from 2005 to 2030. However, owing to the complexity of planning on the energy axis, new studies can and must be conducted in order to achieve the proposed goals as realistically as possible.

The basic assumptions of the Brazilian National Energy Plan are: (a) a growth in GDP; (b) greater supply; (c) energy efficiency and (d) concern over energy security (NATIONAL ENERGY MATRIX 2030, 2005).

The National Energy Plan 2030 aims to establish long-term strategies for expanding the national energy system in accordance with the directives of the National Energy Matrix 2030, defining and analyzing the scenarios for demand, available national resources, the possibilities for importing, alternatives for managing demand, technological developments in the supply of energy and its consumption and environmental constraints (SANTOS; SOUZA, 2011).

It should not be forgotten that hydroelectricity and alcohol (from sugar cane) are the main competitive advantages for Brazil in the field of energy, owing to the abundant number of rivers in the country and the fact that Brazil is a leader in sugarcane technology, which is more economically viable than maize and other sources.

Currently, the greatest challenge to accomplishing the plans for energy investment, environmental licensing, changing rainfall cycles and the distribution 
network which, in addition to not meeting the need to ensure energy security, causes considerable losses to the system.

Furthermore, the authorities are aware of structural bottlenecks that have yet to be resolved by the Brazilian government. However, the guidelines of the public policies in the National Energy Matrix and the Energy Development Plan are focused on preparing the country for:

[...] a future transition from a predominantly hydroelectric expansion, as occurred in the last forty years, to an expansion with completely different characteristics, with a growing share of alternative renewable sources such as wind energy, and thermal power stations, using different, preferably renewable, inputs such as biomass (NATIONAL ENERGY MATRIX 2030, 2005).

In general terms, the country has been following the trends that have proved favorable to developing economies, giving priority to the diversification of the current national energy matrix in order to increase the share of renewable energies. On the other hand, investment in these technologies and the resulting preparation of economic agents to operate with new forms of production requires time. Therefore, in the case of Brazil, renewable energies have yet to become complementary sources to hydroelectricity and there is a long road to run before the country catches up with the levels and standards of developed countries.

\section{PAINTING A PICTURE OF THE CONFLICT}

In Brazil, to meet residential, commercial and most industrial demand, electricity is basically generated by hydroelectric power stations. According to Colacios (2009), in the 1970s, when hydraulic stations were being built and finalized around the country, criticisms were already being voiced about dependence on the water cycle that these stations required, especially the changing courses of the rivers affected by dams.

The Brazilian "blackout" crisis of the late 1990s showed the downside of dependence on the use of hydroelectricity. The lack of planning in the electricity sector combined with an unfavorable rainfall cycle resulted in a troubled year for the economy and discomfort and inconvenience for the Brazilian people (PIRES; FERNANDEZ; BUENO, 2006).

Figure 2 shows the composition of the Brazilian electric matrix with a considerable share for the hydraulic source, despite the reduced supply for two consecutive years. 
Figure 2 - Brazilian electricity matrix

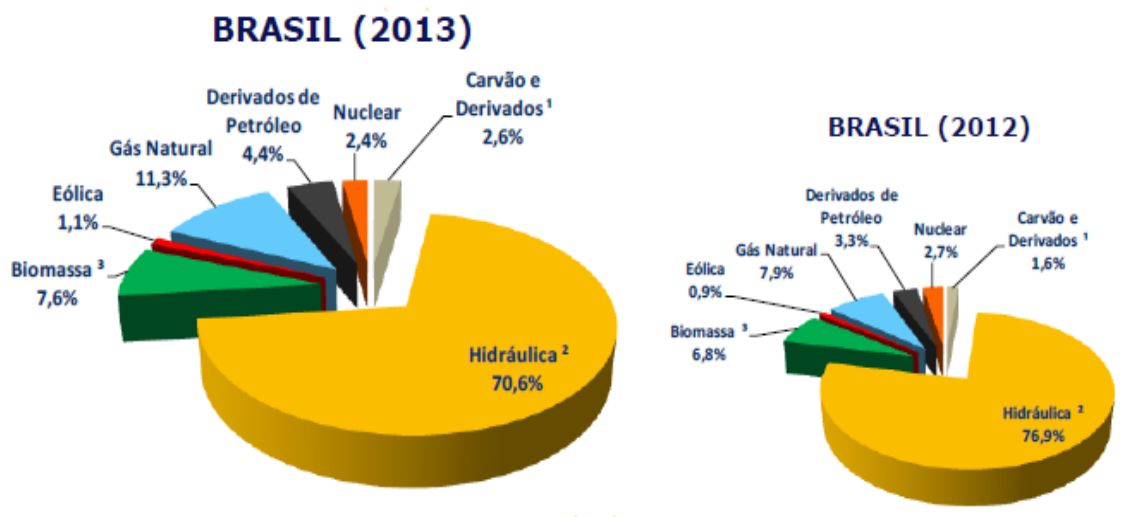

Source: National Energy Balance (2014, p. 29)

Glossary:

biomassa $=$ biomass

eólica $=$ wind

gás natural $=$ natural gas

derivados de petróleo $=$ petroleum products

nuclear $=$ nuclear

carvão e derivados = coal and coal products

hidráulica = hydropower

In spite of its advantages, the hydroelectric expansion model has proved incapable of expanding to the point that supply can match the country's growth. One of the restrictions that has hindered or interrupted current projects is the discrepancy or gap between public policies on the environment and the energy sector.

The reasons behind this gap basically have to do with the lack of compliance or the impossibility of complying with environmental legislation, especially the "lack of a preliminary environmental permit, building projects that have not begun or contractual problems regarding fuel supply"; in addition to the "lack of an installation permit, failure to meet the deadline for initiating a building project, a legal injunction or environmental infeasibility of the project" (PIRES; FERNANDES; BUENO, 2006).

It is worth pointing out that the expansion of the energy structure is planned in isolation and not in step with environmental requirements, running the risk of compromising the sustainable economic development of the country. This 
discourages potential investors, results in higher production costs and lowers Brazil's competitive capacity.

In their eagerness to have projects authorized, people accuse the environmental licensing agencies of being the obstacles to development, barring the construction of hydroelectric power stations and leading the bidding for energy to favor other sources. This is a distorted view of reality, for a number of reasons:

(i) Many entrepreneurs (and even government sectors) take the view that environmental licensing is merely a formality, forgetting the constitutional requirements and the laws that are in force;

(ii) Building projects are often begun before environmental permits are sought;

(iii) Many environmental impact studies are incomplete, and the interested parties delay their conclusion;

(iv) There are macroeconomic aspects, such as rising interest rates, that lead entrepreneurs to prioritize faster building projects;

(v) Certain entrepreneurs seek to streamline the licensing for a project without wishing to embark upon it, wishing merely to sell a "ready-made package" (GOLDEMBERG; LUCON, 2007).

It is important to consider that overcoming these obstacles means compulsory environmental compensation, for which an entrepreneur must allocate at least $0.5 \%$ of the total cost of his project to the creation of new conservation units or the maintenance of existing ones. Other measures are also necessary, such as the adequate resettlement of people affected by the construction of the power station.

"Economizing on these measures is what most delays the expansion of the hydroelectric sector. It is necessary to seek a balance between the interests of those affected by the projects and the interests of much larger populations that will benefit from them far away from where the power plant is built" (GOLDEMBERG; LUCON, 2007).

In addition to the discrepancy between policies, the exclusivist way in which the national environmental policy offers protection is outdated and effectively results in the costs of pollution not being duly collected by the polluting agent. Jenkins and Lamech (1994) understand that, traditionally, regulations by the State have been used to control primary mechanisms for translating environmental policies into benefits and results. In this way, they impose standards for the emission and disposal of products and characteristic processes through the licensing and monitoring established by law.

This is the case with the Polluter Pays Principle. This is a mechanism that discourages behavior that harms the environment by establishing a duty to repair the damage. The polluter is obliged to correct or repair the damage that has been done, paying all the costs and not being allowed to continue causing pollution. 
Thus, all polluters are forced to bear the burden of controlling pollution, without regard for the cost, which is economically inefficient.

As a result, the traditional regulatory approaches are generally insufficient for reducing pollution. The expenditure necessary to comply with environmental laws is increasingly high and is becoming the main production cost. However, this all ends up being passed on to the consumer rather than being met by the polluting companies. Thus, it is the consumer and not the polluter who pays the cost of production and environmental degradation. This makes products more expensive and degrades the environment while the drive for profit is maintained and those responsible for the damage to the environment go unpunished. Furthermore, production costs do not fall, the country does not become more competitive and the environment is not protected.

There is a need for a review of public policies on energy and the environment and the inclusion of strategies to control environmental degradation guided by the market. It is essential to include market instruments that place the cost of environmental degradation on the polluters and not on society. It should be mentioned that these instruments can often make production more costeffective as they provide an ongoing incentive for the development of new technologies and processes to control the emission of pollutants, result in lower administration costs for the State and enable economic development.

The adoption of business strategies related to the environment and the implementation of voluntary systems based on Self-Regulatory Principles related to environmental management in companies has been identified as a current trend. Providing they are duly complemented with the classical mechanisms of command and control, the main advantage of these voluntary systems is the active involvement of the productive sectors in the identification of new opportunities for solutions to environmental problems. They can improve the solution of these problems by improving the relationship between public environmental control agencies and other interested parties and economic agents based on the principles of "governance" (ANDRADE; MARINHO; KIPERSTOK, 2001).

According to Andrade; Marinho and Kiperstok (2001):

It is important for public environment policies to have a tendency to close production cycles, i.e., the establishment of a "zero waste" goal, considering three instances of insertion:

(a) in each production process;

(b) in a situation with segments of the same production chain and/or organizations that are geographically close, that have similar processes or activities or a relationship that involves exchanges with the productive cluster;

(c) in the interface between production processes, consumers and suppliers, involving society as a whole in search of products and services that have minimum negative environmental impacts. 
Another point to be considered is the lack of congruent public policies and regulations in step with economic development and environmental sustainability resulting in scanty investments and few structural projects actually being put into practice. The fact that investors see a risk in relation to the current model of the Brazilian electric sector is a variable that compromises expansion of capacity to generate energy. There are signs of mistrust in Brazilian institutions, and regulatory agencies curb the return on private investments. The construction of a stable and transparent regulatory framework should ensure compliance with contracts and treat both SOEs and private companies equally (PIRES; FERNANDES; BUENO, 2006).

According to Costa and Tiryaki (2011), a World Bank report reveals that 317 billion dollars of resources were earmarked for infrastructure projects with the participation of the private sector between 1993 and 2009. Of this sum, the energy sector absorbed 122 billion dollars. Figure 3 shows which private companies invest most in energy sector projects in Brazil (COSTA; TIRYAKI, 2011):

Figure 3-Países de origem dos investimentos estrangeiros em energia

\begin{tabular}{|c|c|c|c|c|c|}
\hline Empresa & $\begin{array}{l}\text { País de } \\
\text { Origem }\end{array}$ & $\begin{array}{c}\text { US\$ } \\
\text { bilhões }\end{array}$ & Empresa & $\begin{array}{l}\text { País de } \\
\text { Origem }\end{array}$ & $\begin{array}{c}\text { US\$ } \\
\text { bilhões }\end{array}$ \\
\hline Odebrecht & Brasil & 7,1 & Suez & França & 9,7 \\
\hline Camargo Correa & Brasil & 6,2 & Alcoa & EUA & 3,9 \\
\hline CPFL Energia & Brasil & 4,1 & EdP & Portugal & 2,8 \\
\hline EBX & Brasil & 3,0 & Iberdrola & Espanha & 2,1 \\
\hline Vale & Brasil & 2,8 & Abengoa & Espanha & 1,8 \\
\hline Votorantim & Brasil & 2,6 & El Paso Corporation & EUA & 1,8 \\
\hline Previ & Brasil & 2,0 & Elecnor & Espanha & 1,4 \\
\hline Alusa & Brasil & 1,5 & State Grid Corporation & China & 1,0 \\
\hline TAESA & Brasil & 0,99 & Cobra Group & Espanha & 0,82 \\
\hline FIP Brasil Energia & Brasil & 0,93 & Isolux & Espanha & 0,82 \\
\hline
\end{tabular}

Source: World Bank (2009)

Glossary:

empresa = company

país de origem = country of origin

bilhões $=$ billions

frança $=$ france

eua $=$ usa

espanha $=$ spain 
Costa and Tiryaki (2011) affirm that energy projects can be classified as concessions, greenfield and privatizations. In the case of concessions, the private sector assumes the financial and operational risk of the project, which involves the rehabilitation or expansion of already existing assets, with the government retaining ownership. Greenfield means new projects, owned by the private sector or government. Privatizations involve the transfer of ownership of assets to the private sector.

In the case of the energy sector in Brazil, the volume of investments with the involvement of the private sector in greenfield projects is 56,6 billion dollars. For concessions, the amount of investment is 55.9 billion dollars, and in privatizations the total is 9,5 billion. Figure 4 shows to which sector private investments are directed in the energy sector (COSTA; TIRYAKI, 2011):

Figure 4 - Private investments in the energy sector

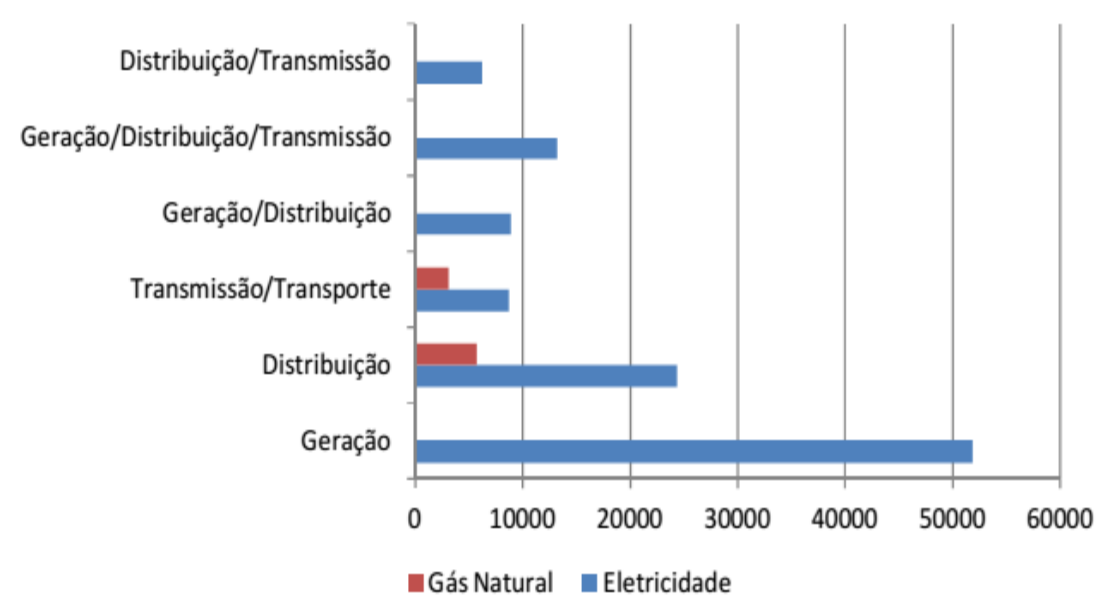

Source: World Bank (2009)

Glossary:

distribuiçãoi/transmissão = distribution/transmission

geração = generation

transporte $=$ transport

gás natural $=$ natural gas

eletricidade $=$ electricity

Another point to analyze is the role of public policies as a form of mediating the inconsistencies identified in the current regulatory framework and the infrastructure of the energy axis. This is not happening at the moment. In addition to a lack of integrated planning, it has been shown that there are an insufficient number of transmission lines, energy is consumed inefficiently and 
subsidies are given to large consumers by the authorities in the energy sector (REIS; FADIGAS; CARVALHO, 2012). As early as 2002, it was discussed that:

\begin{abstract}
The Brazilian electric system suffers technical losses of approximately $15 \%$. This means losses of around 54,000,000 MW/h (or 54 billion kilowatts an hour) from when the electricity is generated in power stations, going through the transmission lines and distribution networks until reaching the end consumer's socket.

If Brazil adopts a loss rate of $6 \%$, which is considered the international standard, the electric system would see a growth in the availability of electric energy equivalent to $33,000,000 \mathrm{MW} / \mathrm{h}$, equal to what is produced in a year at a 6,500 MW power station (or over half of the production of the Itaipu Power Station, which has an installed capacity of $12,600 \mathrm{MW}$ ). The cost of reducing these losses basically consists of improving insulation on the lines and the substitution of old or faulty equipment, such as transformers. These actions are not being carried out as often or as widely as the current situation requires. They would mean much lower costs than the investments made to construct new power plants (BERMANN, 2002).
\end{abstract}

It can also be said that the building of the energy system benefits a respectable number of multinational and transnational companies that operate in Brazil, making decisions decidedly more oriented towards economic benefit in detriment of social and environmental issues (BURSZTYN; BURSZTYN, 2012). Likewise, serious consideration should be given to the fact that for centuries the exploitation of nature had taken place without a balance being made by repairing the effects of this exploitation.

On the other hand, users of electric energy in Brazil, especially the low income groups, face high prices and the current trend that these prices will not fall. The per capita consumption of a Brazilian, according to Tolmasquim (2012) "is very low compared with other countries in the world. It is currently the equivalent of a Chinese person". It is expected that by 2020 there will be an increase to the extent that Brazil will overtake Chile. However, Brazil will remain far behind the per capita consumption of the citizens of France or Spain".

Therefore, the current public energy policy is not in keeping with what is determined by sustainable development, since this would be a balanced advance in the economic, social and environmental field. Providing subsidies to big businessmen, ignoring environmental legislation and burdening the people does not aid long-term growth in the country. Furthermore, this form of policy compromises the competitiveness of Brazil and does not meet demands for environmental protection.

Moreover, electric energy in Brazil is very expensive considering that the sources of generation are abundant and cheap. Table 1 shows the costs of generation that vary according to the source that is used. 
Table 1 -Costs of generation according to the source that is used.

\begin{tabular}{c|c}
\hline Sources & Cost (in U\$\$/kW) \\
\hline Hydroelectric power stations ${ }^{(1)}$ & 1,330 \\
\hline Small hydroelectric stations & 1,200 \\
\hline Co-generation with sugarcane biomass & 900 \\
\hline Wind energy power plants & 1,200 \\
\hline Coal fired thermal power station & 1,600 \\
\hline Natural gas-fired plants & 750 \\
\hline
\end{tabular}

(1) Average considering installations of $88,200 \mathrm{MW}$

Source: Tolmasquim; Guerreiro; Gorini (2007)

Figure 5 shows a comparison of different energy consumption tariffs in different countries and the high price paid for electricity by Brazilian industry.

Figure 5 - Industrial electricity consumption tariffs (selected countries) (R\$/MWh)

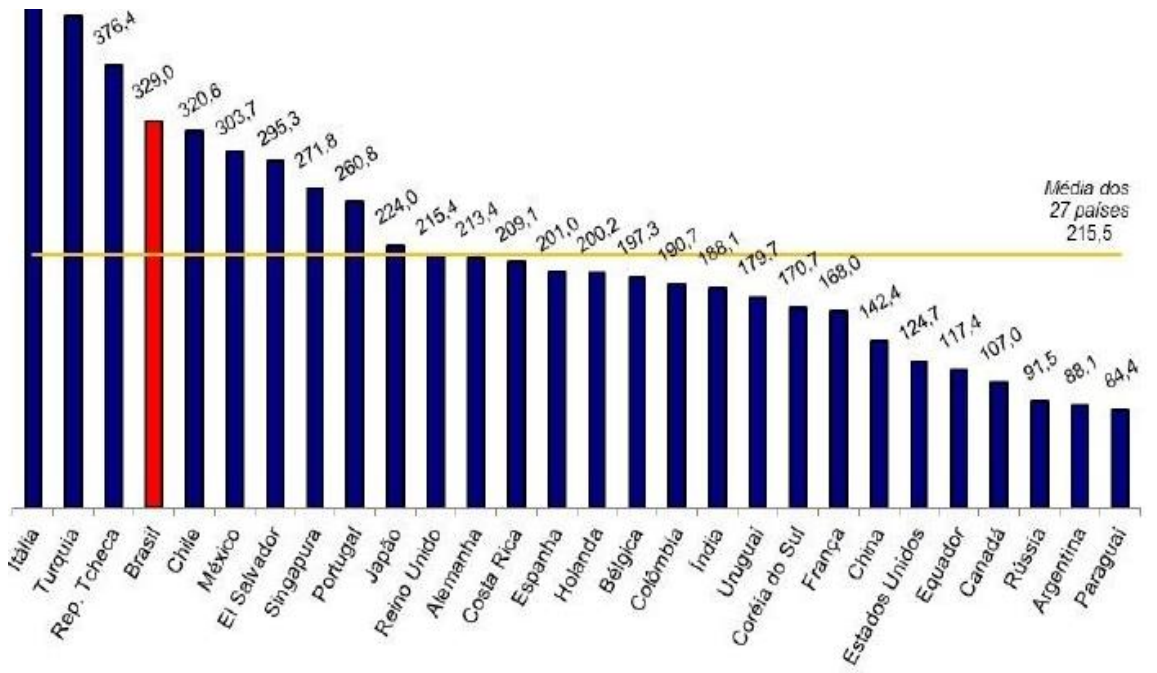

Note: prices converted to Real PPP 1.834 R\$/USS (OCDE, 2011)

Source: Energy Sector Portal (2012)

Glossary:

Average of the 27 countries 215.5

Itália: Italy

Turquia: Turkey

República Tcheca: Czech Republic 
Brasil: Brazil

México: Mexico

Singapura: Singapore

Japão: Japan

Reino Unido. United Kingdom

Alemanha: Germany

Espanha: Spain

Holanda: The Netherlands

Bélgica: Belgium

Colômbia: Colombia

Índia: India

Uruguai. Uruguay

Cora do sul: South Korea

França: France

Estados Unidos: United States

Equador: Ecuador

Canadá: Canada

Rússia: Russia

Paraguai: Paraguay

According to Mendonça (2012), the average tariff of $329.0 \mathrm{R} \$ / \mathrm{MWh}$ for Brazilian industry is over $50 \%$ higher than the average of $215.50 \mathrm{R} \$ \mathrm{MWh}$ for a set of 27 countries for which data are made available by the International Energy Agency.

A comparison of the industrial energy tariffs of the BRICs countries shows that the tariff in Brazil is $134 \%$ higher than the average for the countries in this group (140.7 R\$/MWh), as shown in Figure 6: 
Figure 6 - Industrial electricity tariffs of the BRICs - Brazil, Russia,

\begin{tabular}{|c|c|}
\hline Paises & Tarifa média (R\$/MWh) \\
\hline Brasil & 329,0 \\
\hline Índia & 188,1 \\
\hline China & 142,4 \\
\hline Rússia & 91,5 \\
\hline $\begin{array}{c}\text { Média de Rússia, } \\
\text { Índia, China }\end{array}$ & 140,7 \\
\hline
\end{tabular}

Source: Electricity Sector Portal (2012)

Glossary

Países: Countries

Tarifa média: Average tariff

Média da Rússia, Índia e China: Average of Russia, India and China

Likewise, compared with its four main commercial partners (USA, Argentina, Germany and China), Brazil has an electricity tariff for industry that is far higher than the international standard, as shown in Figure 7. An analysis of the tariffs practices in different states of the federation shows that no state has a competitive electricity tariff compared with the world average, the average of the BRICs, the main countries of Latin America or Brazil's major commercial partners.

Figure 7 - Industrial electricity tariffs in Latin America ( $\mathrm{R} \$ / \mathrm{MWh})$

\begin{tabular}{|c|c|}
\hline Paises & Tarifa média (R\$/MWh) \\
\hline Brasil & 329,0 \\
\hline Chile & 320,6 \\
\hline México & 303,7 \\
\hline El Salvador & 295,3 \\
\hline Colômbia & 190,7 \\
\hline Uruguai & 179,7 \\
\hline Equador & 117,4 \\
\hline Argentina & 88,1 \\
\hline Paraguai & 84,4 \\
\hline $\begin{array}{c}\text { Média dos vizinhos latinos } \\
\text { (Argentina, Chile, Colômbia, El Salvador, }\end{array}$ & 197,5 \\
\hline
\end{tabular}


Glossary

Brasil: Brazil

México: Mexico

Colômbia: Colombia

Uruguai. Uruguay

Equador: Ecuador

Paraguiai: Paraguay

Média dos vizinhos latinos: Average of Latin American neighbors

Barroso, Rosemblat and Veiga (2014) understand that the Brazilian energy sector is currently fragile because of the new model adopted by the sector in 2004. There have been financial losses and serious problems in all sectors. A number of distributors did not see their contracts renewed in late 2012, as there was no bidding to renew energy contracts. Consequently, "the distributors had to purchase record quantities of energy as a result of the difference between consumption and the quantities purchased on the short-term market in 2013 and 2014, at which time prices were also at a record high". This led to a financial "hemorrhage" and required billions in investments from the National Treasury and public and private banks, resulting in very high increases in tariffs in 2014 and 2015. Furthermore, since 2010, there has been a long period of drought in several regions of the country, which resulted in a sharp drop in the water levels in the reservoirs of Brazilian hydroelectric plants.

Since late 2012, there has been ongoing action by the entire thermoelectric sector to guarantee the electricity supply. In 2013, when hydrology was very close to the historical average ( $96 \%$ of the LTA), the thermal power stations were activated at a cost of twenty-five billion reais, while the reservoirs were significantly emptied. The combination of the rapid depletion of the reservoirs and the continuous activation of the thermal plants resulted:

[...] in record prices on the short-term market, putting financial pressure on thermal generators (due to the need to purchase energy at high prices on the spot market) and the hydroelectric power stations (which, due to the reduced production of the plants, have billionaire expenses on the short-term market to honor their contractual obligations) (BARROSO; ROSEMBLAT; VEIGA, 2014).

Figure 8 shows the bad Pareto situation (Pareto Optimality will occur when there is a situation $(A)$ by which one subject has to win and at least one has to lose. Thus, an economic situation is optimal in the Pareto sense if it is not possible to improve the situation of one agent without aggravating the situation 
of any other economic agent. See: www.econometrix.com.br/pdf/a-lei-daeficiencia-de-pareto.pdf), of the Brazilian energy sector owing to a combination of factors, including: i) managerial problems that resulted in insufficient purchases by distributors; (ii) a lack of planning that resulted in problems in the performance of the generation and transmission system not being corrected; and (iii) the implementation of measures that deeply affected the sector. These measures included Decree 579 (this decree became Law 12.783, of 11 January 2013 , regulating concessions for the generation, transmission and distribution of electricity, tax reductions in the sector and the moderation of tariffs) and CNPE Resolution 03/2013 (it establishes a directive for the internalization of risk aversion mechanisms in computer programs for energy studies, price setting and other arrangements), in the short term, with no opportunity for discussions between government and agents, which jointly led to a downward spiral and an environment of uncertainty, mistrust and lost credibility in the Brazilian electricity sector (BARROSO; ROSEMBLAT; VEIGA, 2014).

There is a lack of coordination among the agencies in the Brazilian electricity sector. This, combined with a lack of investment in infrastructure and excessive regulations by the National Electricity Agency, deters potential agents from the private sector who might be interested in sharing the risks with the Brazilian government. The Ministry of Mines and Energy is currently the agency responsible for national energy planning and the enforcement of the policies determined by the National Energy Policy Committee (TEN-YEAR ENERGY EXPANSION PLAN 2024, 2015).

Figure 8-Bad Pareto Situation of the Brazilian electricity sector in 2014

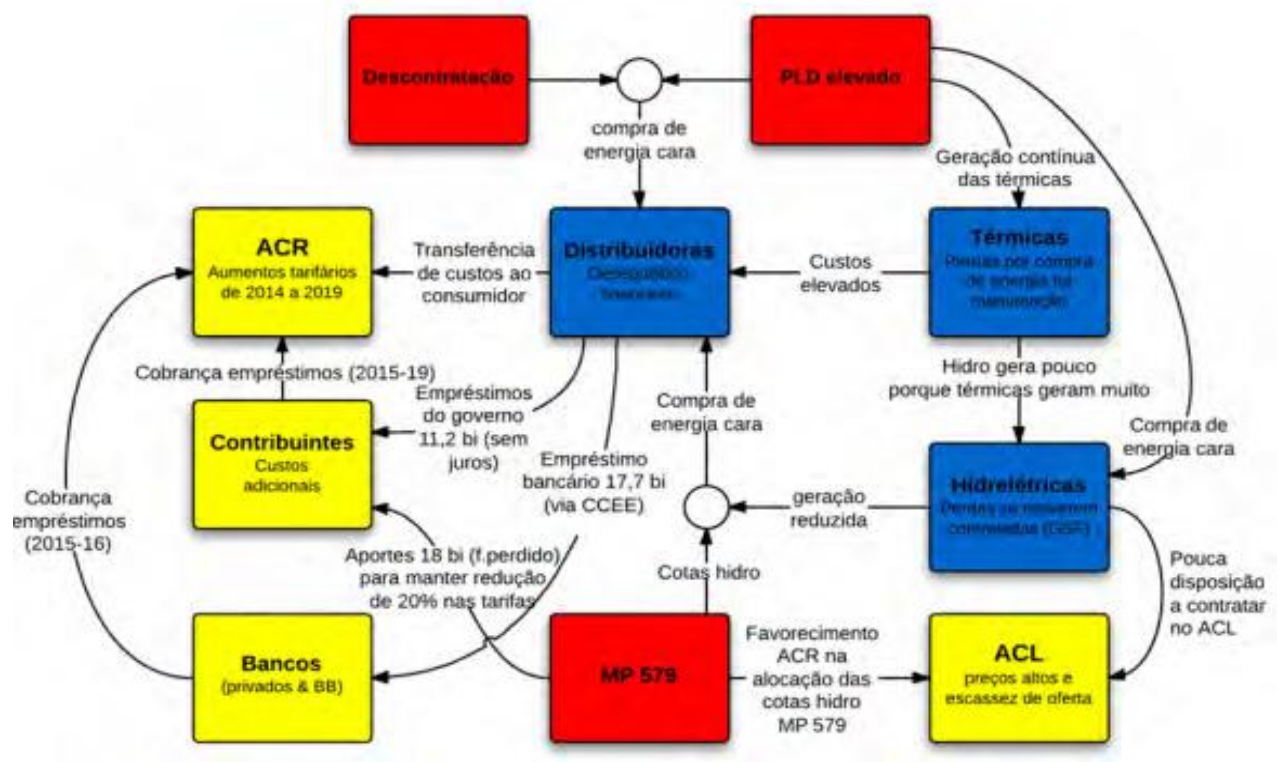

Source: BARROSO; ROSEMBLAT; VEIGA, 2014. 
Glossary

Cobrança Empréstimos (2015-2016): Collecting on loans (2015-2016)

ACR Aumentos tarifários de 2014 a 2019: Regulated Contracts Tariff increases from 2014 to 2019

Cobrança empréstimos: Collecting on loans

Contribuintes Custos adicionais: Taxpayers Additional costs

Bancos (privados \& BB): Banks (private and BB)

Descontratatação: Decontracting

Transferência de custos ao consumidor: Transfer of costs to the consumer

Empréstimos do governo 11.2. bi (sem juros): Government loands of 11.2 billion (interest free)

Aportes 18 bi (f. perdido) para manter redução de 20\% nas tarifas:Investments totaling 18 billion (Aportes 18 bi (non-repayable) to maintain 20\% reduction on tariffs

Compra de energia cara: Purchase of expensive energy

Distribuidoras desequilíbrio: Imbalance of distributors

Compra de energia cara: Purchase of expensive energy

Empréstimo bancário 17.7 bi (via CCEE): 17.7 billion bank loan (through the CCEE)

Cotas hidro: Hydro quotas

MP 579: Decree 579

PLD elevado: High price difference settlement

Custos elevados: High costs

Geração reduzida: Reduced generation

Favorecimento ACR na alocação das cotas hidro MP 579: Favoring Regulated Contrcts in the allocation of hydro quotas, Decree 579

Geração contínua das térmicas: Continuous generation of thermal plants

Térmicas Perdas por compras de energia na manutenção: Thermal plants Losses through purchase of energy in maintenance

Hidrelétricas: Hydroelectric plants

Página | 325

ACL Preços altos e escassez de oferta: Free contracting High prices and low supply 
Compra de energia cara: Purchase of expensive energy

Pouca discposição de contratar no ACL: Unwillingness to adopt flexible contracts

The price of electricity is one of the indicators that compromises the weak competitiveness of Brazilian products on the domestic and international market. In 2015, Brazil fell eighteen places in the competitiveness ranking, coming 75th place in the Global Competitiveness Report (2014-2015) - the report claims that countries with low rates of competitiveness are characterized by weak institutions, deficient infrastructure, non-inclusive, low quality education and a healthcare system that is incompatible with the needs of the people, published by the World Economic Forum (SEBRAE, 2015). It should be noted that there was an increase of $44 \%$ in installed capacity from 2005 to 2015, an average of 4.323 MW per year. However, in the Global Competitiveness Index, the country fell 21 places when it came to electricity supply (MONTEIRO, 2015; RUFINO, 2015).

Electricity in Brazil is more expensive today than it was ten years ago. This could be related to the lack of public policies to mediate the contradictions identified in the regulatory framework and the energy axis infrastructure. In addition to the lack of integrated planning an insufficient transmission lines, the authority of the electricity sector has subsidized large consumers, and energy efficiency has not realized its full potential (REIS; FADIGAS; CARVALHO, 2012).

The Brazil Cost, which reflects the cost of inefficiency in the economy, is directly affected by the cost of energy. According to Sauer (2013), the explanation for high tariffs in Brazil "has to do with the model, the contracting, how the winners are chosen, how contracts are made, how risks are perceived by these individual agents, and later in the chain they are transferred to the tariffs $[\ldots]^{\prime \prime}$.

Finally, according to Bermann (2002), hydroelectric enterprises often prove to be unsustainable, at both the worldwide level and in Brazil. This is because of the criteria that identify physical, chemical and biological problems resulting from the implementation and operation of a hydroelectric power station, its interaction with the characteristics of the environment of its locus, particularly in relation with the riverside populations that are affected by the construction works. Brazilian hydroelectric plants have been responsible for the flooding of over $34,000 \mathrm{~km} 2$ of land for the formation of reservoirs and the "compulsory displacement" of approximately two hundred thousand families.

The building of a hydroelectric power plant for these people often means the destruction of their life projects, forcing them out of their land with no compensation that could least guarantee their conditions for reproduction at the level to which they were accustomed prior to the implementation of the enterprise in question.

These works lead to the forced displacement of these people with paltry financial compensation or none at all. The resettlement process, when there is one, does not guarantee their previous living 
conditions. In areas surrounding dams, there are a number of public health problems such as an increase in endemic diseases, compromised water quality in the reservoirs that affect fishing and agriculture and greater risk of floods below the reservoirs as a result of operational problems. Furthermore, large areas of farmland are submerged and, in many cases, there is an irreversible loss of biodiversity (BERMANN, 2002).

All these elements show that the environmental protection policies and economic development policies, principally in the energy sector, are out of step, making it impossible to protect the environment effectively, adversely affecting the competitiveness of the country and increasing the Cost Brazil index.

According to Castro, Dantas and Timponi (2011), and as shown in Table 2, the environmental impacts of generating electricity vary, especially in its spatial dimension, when considering the difference between local and regional impacts and the global impact of climate change. These differences lead to different perceptions on the part of the agents involved. It can be highlighted that in light of this it is necessary for an evaluation of the impact of expanding an electric system to be coordinated to avoid this differentiated perception of the agents gaining an advantage over the interests of society as a whole. Furthermore, these differences show that the environmental impacts of an expanding electric system should indeed result in the choice of ventures with less of an impact, and for this to happen, it has to be aligned with the planning of the sector. It should be emphasized that this was the original purpose of evaluating environmental impact, but it has now become commonplace to link evaluations of environmental impact to the licensing of the venture, and these evaluations have now come to be focused on specific projects.

Table 2 - Social and environmental impacts generating electricity from different sources

\begin{tabular}{|c|r|}
\hline SOURCES & SOCIAL AND ENVIRONMENTAL IMPACTS \\
\hline Thermoelectricity & Emission of greenhouse gases, particulate matter and SOx. \\
\hline Hydroelectricity & $\begin{array}{r}\text { Flooding to construct dams, altering downstream river regimes, } \\
\text { silting upstream of the dam, barriers against fish migration, } \\
\text { proliferation of algae, Loss of historical and archeological heritage } \\
\text { and tourism. Removal of local populations. }\end{array}$ \\
\hline Bioelectricity & $\begin{array}{r}\text { Loss of biodiversity, atmospheric pollution, fish mortality, } \\
\text { contamination of groundwater and aquifers. }\end{array}$ \\
\hline Wind energy & Noise pollution, aesthetic pollution and death of birds. \\
\hline Solar energy & Accumulated toxic residue in the environment. \\
\hline SHPs & Interference in local flora and fauna. Conflicts with tourism. \\
\hline Nuclear energy & Risk of accidents. Uncertainty in residue management. Danger of \\
proliferation of atomic weapons.
\end{tabular}

Source: GOLDEMBERG; LUCON (2007); CASTRO; DANTAS; TIMPONI (2011) 
A reflection on the role of energy in the Brazilian economy shows that it is not an end, but part of the nation's economic development. Hydroelectricity is still the most commonly used source for the generation of electric energy, although the change to an electric matrix with new sources is expected to take place in the future, as the current model has proved to be fragile and precarious for the infrastructure that the country has at its disposal, requiring bolder measures. Therefore, the directives of the energy policy should be aligned and integrated with the other goals and plans for national economic development, projecting long-term scenarios (BARROS, 2014), which has so far not been the case in Brazil.

\section{CONCLUSIONS AND SUGGESTIONS FOR FURTHER STUDIES}

The most serious problem concerning the clash between economic development and environmental protection is deciding, while striving for maximum efficiency, which would cause more harm to society and should be avoided. It appears to have been decided in the Brazilian legal system that between economic development and environmental protection, the Brazilian state will always come down on the side of the environment.

But in this they are not alone. On a global scale, since the last decades of the twentieth century, there has been a reversal in environmental property rights, which has altered the cost of their transaction. The market has come to give greater value to environmental property, which enables the continued existence of the human race, than to the consumption of products that lead to devastating environmental degradation and could determine the extinction of the human race on this planet. In this light, public opinion has transferred responsibility for these negative effects on the environment to the producers of goods that cause pollution.

The market itself has taken on the task of transferring environmental property rights. Consequently, manufacturers increasingly internalize the external polluting effects of their production, leading to increased costs for their companies. If manufacturers have to incur these costs, it is because environmental balance has become more important to people than the value of the goods whose production processes have a polluting effect.

Therefore, Brazil has concentrated its efforts on expanding economic growth sustainably and within the limits of current environmental legislation. In this context, the environmentally sustainable bias of hydroelectric power stations is being questioned because the construction and operation of these complexes result in a variety of social and environmental problems with a difficult trade-off.

One tool that can aid a more balanced and consistent environmental policy and policy for the energy matrix is the use of the Strategic Environmental Assessment (SEA). According to Souza and Santos (2011) this tool consists of: 
managing negative effects and the consequences of initiatives and proposals (Souza; Santos, 2011).

It should be noted that there is no concrete definition of the kinds of investment that require a Strategic Environmental Assessment. It will obviously be required in cases in which the level of environmental impairment is high and the trade-off that is expected between the probable environmental interference and economic and social gains will be difficult to achieve. However, it is known that investments in the energy sector as a rule produce negative external effects to the environment and for this reason the SEA is an efficient instrument to aid strategic decision making on investments to promote the three levels of sustainable development.

The Brazilian Federal Government, through the Ministry of the Environment has already encouraged and trained public managers to use the SEA in decision making in their own sectors. Since 2002, the Ministry has used the SEA as part of its Institutional Strengthening Program for Environmental licensing. Furthermore, the National Audit Office also recommends using the SEA for the preparation of the Multiyear Plan and for planning sectorial policies and programs in the country.

Nevertheless, an analysis of the "main procedures and content of the National Energy Plan 2030 shows a strong planning structure in economic models, but a weak one in ecological models, to such an extent that despite discourse on the definition of a strategy for expanding the supply of energy from a viewpoint of sustainable development of the country, the National Energy Plan 2030 does not actually include the environmental variable in the decision making process" (SOUZA; SANTOS, 2011).

Some examples of this "environmental weakness" can be given. One of them is the case of inventory and diagnostic studies that, despite admitting the existence of some "potential social conflicts" (in relation to conservation units, indigenous lands, quilombos (African settlements), extractive reserves and sustainable development policies for regions with a hydroelectric potential), only describe the issue in general terms. Therefore, it is not possible to say whether this information was considered during decision making. Another example is the compatibility of goals for environmental protection, which are relegated to the lower levels of the hierarchy of planning, which is centered essentially on obtaining environmental permits for energy projects.

All this leads to the conclusion that "the approach with the environmental variable is insufficient for making environmental feasibility compatible with the forecast actions of the plan. Furthermore, the procedures for communication between the different levels (institutional, technical and scientific and the community) have not enabled compatibility between the strategic goals and the national interest in terms of environmental protection and sustainability" (SOUZA; SANTOS, 2011).

Although the formulation of the National Energy Plan has been found to be out of step, as shown throughout this text, this perspective can change when the 
strategic plan is put into action. With decision making guided by the tools of the SEA, the following results are possible:

1. An integration of the economic and market factors with those of the environment, with the environment as the determining factor in decision making.

2. The SEA aids the formulation of an environment database to support sustainable management decisions when dealing with a certain energy project, its development in relation to the use of environmental resources and resulting negative external environmental factors.

3. This tool enables the early identification of controversial issues that may arise during the project, especially in the environmental licensing phase.

4. The SEA can also help the country to be more energy efficient because it includes elements for evaluating and establishing sustainable alternatives for energy expansion, identifying actions that can reduce environmental impact and better tools for managing the negative environmental impacts of the project.

All these possibilities can help to make the project more efficient in terms of economic gains and environmental protection because the effects of the decisions can be better monitored, both in terms of forecasted results and the unexpected events that may arise. Furthermore, there could be integration between the three facets present throughout this process: the law, economics and the market.

This can only bring improved conditions for sustainability in the country because a legal system that is concerned with efficiency and the costs of complying with its norms draws much closer to the ideal of justice. An economic theorem that takes public policies into account that were adopted at a certain time or place will be much more efficient and have greater chances to explain economic phenomena. A market that takes regulations, ideals of justice, costs and benefits and ways of being into account will certainly have better conditions for growth.

Therefore, from this dialogue between the different facets, it will be possible to strike a balance for each to harmonize their goals and see a market that grows efficiently and justly. There will be a legal system that regulates behavior and consider not only justice but the cost-benefit and efficiency of legislative choice and an economic theorem concerned with efficient and just development. 


\section{Breves considerações sobre o conflito entre proteção pública ambiental e políticas de proteção do desenvolvimento econômico e as suas conseqüências para expansão de energia no Brasil}

\section{RESUMO}

O presente trabalho tem como objetivo fazer breves considerações sobre o planejamento da infra-estrutura energética, o desenvolvimento econômico brasileiro e do meio ambiente. Esta análise será realizada com base nas políticas públicas conflitantes para o desenvolvimento econômico e proteção ambiental. Este conflito traz dificuldades de planejar a expansão do setor energético brasileiro de forma eficiente, reduz a capacidade competitiva do país e não fornece uma protecção ambiental adequada. O problema mais grave relativo ao confronto entre o desenvolvimento econômico e a proteção ambiental é decidir, enquanto se esforça para a máxima eficiência, o que causaria mais danos à sociedade e deve ser evitado. No sistema jurídico brasileiro entre o desenvolvimento econômico e a proteção ambiental, o Estado brasileiro sempre virá para baixo no lado do meio ambiente. Considerando os objetivos propostos, o estudo envolverá a consulta de documentos e literatura, além de pesquisa exploratória.

PALAVRAS-CHAVE: Sustentabilidade. Desenvolvimento Econômico. Políticas Públicas. 


\section{REFERENCES}

ANDRADE, José C. S.; MARINHO, Márcia M. O.; KIPERSTOK, Asher. Uma política nacional de meio ambiente focada na produção limpa: elementos para discussão. BAHIA ANÁLISE \& DADOS Salvador - BA SEI v.10 n.4 p. 326-332 Março 2001.

ARAÚJO, Suely M. V. G de. Licenciamento ambiental e Legislação. 2002.

Disponível em:

$<$ http://www.bibliotecaflorestal.ufv.br/bitstream/handle/123456789/9876/texto Licenciamento-Ambiental-e-Legisla\%C3\%A7\%C3\%A3o Camara-

Deputados.pdf?sequence=1>. Acesso em: 23 Out 2014.

BALANÇO ENERGÉTICO NACIONAL. Relatório síntese ano base 2013. Disponível em <http:// ben.epe.gov.br/BENRelatorioSintese2013.aspx> Acesso em: 29 Ago 2013.

BARROSO, Luis A.; ROSEMBLATT, José.; VEIGA, Mario. Setor elétrico brasileiro: estado atual e sugestões. In: Visões do Setor Elétrico: Uma contribuição para o futuro energético do Brasil. Disponível em:

$<$ http://visoesdosetoreletrico.com.br/livro/livro papers visoes setoreletrico.pdf >. Acesso em: 28 Fev 2016.

BARROS, Rui F. de. Política energética/segurança nacional. Instituto de Defesa Nacional. Ano IX;№ 31 (Jul-Set 1984). Disponível em:

http://comum.rcaap.pt/handle/123456789/2794. Acesso em: 25 Mar 2014.

BRANCO, Zillah M. Vida e luta de Catullo Branco: raízes do sentimento de nacionalidade e da vocação revolucionária. In: BRANCO, Adriano Murgel (Org.) Política energética e crise de desenvolvimento: a antevisão de Catullo Branco. São Paulo: Paz e Terra, 2002.

BERMANN, Célio. A perspectiva da sociedade brasileira sobre a definição e implementação de uma política energética sustentável - uma avaliação da política oficial. 2002. Disponível em:

<http://www.riosvivos.org.br/arquivos/571566216.pdf>. Acesso em 22 Out 2014.

BURSZTYN, Marcel; BURSZTYN, Maria A. Fundamentos de política e gestão ambiental: os caminhos do desenvolvimento sustentável. Rio de Janeiro: Garamond, 2012. 
CARVALHO, Claudio E. Energia, recursos naturais e a prática do desenvolvimento sustentável. 2.ed. rev. atual. Barueri, SP: Manole, 2012.

CASTRO, Nivalde J. de.; DANTAS, Guilherme de A.; TIMPONI. Raul R.A Construção de Centrais Hidroelétricas e o Desenvolvimento Sustentável. Revista Economia e Energia, № 81, 2011.

COLÁCIOS, Roger D. Matriz energética brasileira: consolidação, expansão, políticas e meio ambiente (1971-1979). Revista Territórios e Fronteiras V.2 N.1 Jan/Jun 2009. Disponível em:

http://www.ppghis.com/territorios\&fronteiras/index.php/v03n02/article/view/4 0. Acesso em: 01 Jun 2014.

CONSTITUIÇÃO DA REPÚBLICA FEDERATIVA DO BRASILCONVENÇÃO DE ESTOCOLMO SOBRE AMBIENTE HUMANO.EPE - Empresa de Pesquisa Energética. Brasil: renováveis para o desenvolvimento. Cartilha EPE Rio+20, 2012. Disponível em: http://www.epe.gov.br/MeioAmbiente/Documents/Cartilha\%20EPE\%20\%20Riomais20.pdf. Acesso em: 30 Mai 2014.

COSTA, Marcelo. TIRYAKI, Gisele F. Investimento privado no setor de energia do brasil: evolução e determinantes. In: revista eletrônica de energia. v. 1, n.1, p. 34-57, jul./dez. 2011.

EUROPEAN RENEWABLE ENERGY COUNCIL - EREC.GREENPEACE. [r]evolução energética: a caminho do desenvolvimento limpo. São Paulo: Pigma, 2010. Disponível em:<http://www.greenpeace.org/brasil/Global/brasil/report/2010/11/revolucao energeticadeslimpo.PDF>. Acesso em 13 Set 2013.

FERRAZ, Roberto C.Instrumentos econômicos de proteção ao meio ambiente. .A macrológica do mercado.

Tributação ambientalmente orientada e espécies tributárias no Brasil. In: TORRES, Heleno Taveira. Tributação ambiental. São Paulo: Malheiros, 2005.

FREITAS, Giovana S. As modificações na matriz energética brasileira e as implicações para o desenvolvimento socioeconômico e ambiental. Tese (Doutorado em Economia). Programa de Pós Graduação em Economia. Universidade Federal do Rio Grande do Sul. Faculdade de Ciências Econômicas. Porto Alegre, 2011. Disponível em: < 
http://www.lume.ufrgs.br/bitstream/handle/10183/40251/000822367.pdf?sequ ence $=1>$. Acesso em:28 Set 2013.

GLENN, Jenkins. LAMECH.Ranjit.Green taxes and incentive policies.capítulo I.

GOLDEMBERG, José. Energia e desenvolvimento sustentável. São Paulo: Blucher, 2010.Série Sustentabilidade; v.4.

GOLDEMBERG, José. LUCON, Oswaldo. Energia e meio ambiente no Brasil. Estudos Avançados 21 (59), 2007.

LEITE, Antonio Dias. A economia brasileira: de onde viemos e onde estamos. 2 ed. [rev. e atual.] Rio de Janeiro: Elsevier, 2011.

MENDONÇA, Luciana. Questão de competitividade. Revista do Setor elétrico, $\mathrm{n}$. 으 77, 2012.

MONTEIRO, Solange. Alta tensão: empresas e governo buscam convergência para reposicionar a oferta do setor elétrico na rota da segurança de abastecimento a preços competitivos. Conjuntura Econômica. Setembro 2015. v.69 no 09.

PIRES, Adriano; FERNANDEZ, Eloi F.; BUENO, Julio C. C.. Política energética para o Brasil: propostas para o crescimento sustentável. Rio de Janeiro: Nova Fronteira, 2006.

PORTAL DO SETOR ELÉTRICO. Disponível em: $<$ http://www.osetoreletrico.com.br>.

REIS, Lineu B. dos.; FADIGAS, Eliane A. F. A.; CARVALHO, Claudio E.. Energia, recursos naturais e a prática do desenvolvimento sustentável.2.ed. rev. atual. Barueri, SP: Manole, 2012.

RUFINO, Romeu. Energia em foco: estratégias e desafios para o futuro. Cenário e perspectivas para o setor elétrico brasileiro. Fundação Getúlio Vargas. Notas de palestra proferida em 28 de agosto de 2015. Disponível em:<http://fgvenergia.fgv.br/sites/fgvenergia.fgv.br/files/apresentacao cenario perspectivas do setor ee dr romeu 2708 15.pdf>. Acesso em: 18 jan. 2016.

SANTOS, Simone M.. SOUZA. Marcelo P. de. Análise das contribuições potenciais 
SAUER, Ildo. Política energética. Estud. 2013, v.27, no.78, 2013. Disponível em: <http://dx.doi.org/10.1590/S0103-40142013000200015>. Acesso em: 19 mar. 2015.

TOLMASQUIM, Mauricio T.Perspectivas e planejamento do setor energético no Brasil. Estud. av. [online]. 2012, vol.26, n.74, pp. 247-260.

TOLMASQUIM, Mauricio T.; GUERREIRO, Amilcar; GORINI, Ricardo. Matriz energetica brasileira. Novos Estudos: CEBRAP. Novembro 2007 pp. 47-69.

Como citar: MYSZCZUK, A. P.; SOUZA, A. Brief considerations on the conflict between public environmental protection and economic development policies and their consequences for energy expansion in Brazil. R. bras. Planej. Desenv.,Curitiba, v. 5, n. 2, p. 305-335, mai./ago. 2016. Disponível em:

$<$ https://periodicos.utfpr.edu.br/rbpd>. Acesso em: XXX.

Correspondência:

Ana Paula Myszczuk

Av. Sete de Setembro, 3165 - Rebouças, Curitiba, PR.

Direito autoral: Este artigo está licenciado sob os termos da Licença CreativeCommons-Atribuição 4.0

Internacional. 